\title{
A CASE REPORT OF FEMALE PATIENT WITH LARYNGEAL GRANULOMA
}

Sladjana Simovic ${ }^{1}$, Tatjana Sarenac Vulovic ${ }^{2,4}$, Jasmina Stojanovic ${ }^{3}$, Sandra Zivanovic ${ }^{4}$, Mladen Koravovic ${ }^{5}$

${ }^{1}$ Department of Otorhinolaryngology, Health Centre Kragujevac, Kragujevac, Serbia

${ }^{2}$ Clinic of ophthalmology, Clinical centre Kragujevac, Kragujevac, Serbia

${ }^{3}$ Phoniatric department of ENT Clinic, Clinical centre Kragujevac, Kragujevac, Serbia

${ }^{4}$ Faculty of Medical Sciences, University of Kragujevac, Kragujevac, Serbia

${ }^{5}$ Faculty of Pharmacy, University of Belgrade, Belgrade, Serbia

\author{
PRIKAZ SLUČAJA BOLESNICE SA LARINGEALNIM GRANULOMOM

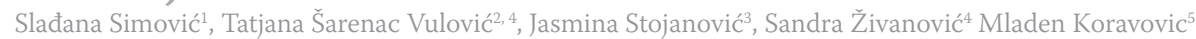 \\ ${ }^{1}$ Odeljenje otorinolaringologije, Dom zdravlja Kragujevac, Kragujevac, Serbija \\ ${ }^{2}$ Klinika za oftalmologiju, Klinički centar Kragujevac, Kragujevac, Serbija \\ ${ }^{3}$ Odsek za fonijatriju, Klinika za otorinolaringologiju, Klinički centar Kragujevac, Kragujevac, Serbija \\ ${ }^{4}$ Fakultet medicinskih nauka, Univerzitet u Kragujevcu, Kragujevac, Serbija \\ ${ }^{5}$ Farmaceutski fakultet Beograd, Univerzitet u Beogradu, Beograd, Srbija
}

Received / Primljen: 02. 02. 2016.

Accepted / Prihvaćen: 20. 05. 2016.

\begin{abstract}
The aim of this case report is to present the laryngeal granuloma in 23 year old female patient. Case outline: The 23 year old female was admitted for examination, because of long lasting, progressive hoarseness. In anamnesis, we found that she has undergone general anesthesia for 8 times, in the early childhood. We performing direct laryngoscopy with complete otorhinolaryngologic examination, rigid endovideostroboscopy and the large granuloma of the larynx was found. Conclusions: Laryngeal granuloma of vocal cords affected mainly men, except for cases associated with laryngeal intubation. We should keep in mind that postintubation laryngeal granuloma might develop after tracheal intubation, so care must be taken to avoid the potential complication.
\end{abstract}

Keywords: laryngeal granuloma, treatment, predisposing factors.

\section{SAŽETAK}

Cilj ovog rada je da prikažemo slučaj granuloma larinksa kod bolesnice ženskog pola. Prikaz bolesnika: Bolesnica starosti 23 godine, javila se zbog dugotrajne, promuklosti. $U$ anamnezi ove bolesnice dobijamo podatak da je kod nje, tokom ranog detinjstva 8 puta bila primenjena endotrahealna intubacija. Tokom dijagnostičke evaluacije primenjena je direktna laringoskopija, kompletan otorinolaringološki pregled i rigidnu endovideolaringostroboskopija $i$ uočen je laringealni granulom. Zaključak: Laringealni granulom je benigni izraštaj koji je češci kod osoba muškog pola, osim u slučajevima kod kojih je primenjivana endotrahealna intubacija. Trebalo bi imati u vidu da bi laringealni granulom mogao da se razvije posle primene endotrahealne intubacije, pa treba preduzeti sve mere da bi se izbegla ova potencijalna komplikacija.

Ključne reči: laringealni granulom, terapija, predisponirajući faktori.

\section{ABBREVIATIONS}

LG- Laryngeal granuloma

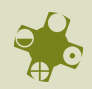

\section{INTRODUCTION}

Laryngeal granuloma (LG), first described by Chevalier Jackson in 1928 as "contact ulcer of the larynx," is known in the literature by many names, including laryngeal contact ulcer, contact granuloma, vocal fold granuloma, postintubation granuloma, vocal process granuloma and arytenoid granuloma (1).

Laryngeal granuloma is benign growth that resembles tumor by its macroscopic appearance, but not by its biological-histological characteristics and that is why it is classified as pseudo tumor. Laryngeal granuloma is a nonspecific inflammatory process formed by granulation tissue that occurs primarily in the vocal process of arytenoids cartilage $(2,3)$. Incidence and prevalence of LG in general population are not clearly evaluated. They occur in about $0,9-2,7 \%$ of adults with voice disorders (2). The localization and appearance of the LG is very characteristic. The main etiopathogenic factor associated is laryngopharyngeal reflux, followed by laryngeal intubation and vocal abuse. The correct diagnosis can be established only by clinical examination, but the histological examination is necessary in order to avoid misdiagnosis (4). Clinical treatment is based on the use of proton pump inhibitor, topical corticoid and speech therapy and also surgical therapy in laryngomicrosurgery (5). The aim of this case report is to present the LG in 23 year old female with a complex medical history. 


\section{CASE REPORT}

The 23 year old female student was admitted for examination to Department of Otorhinolaryngology Health Centre Kragujevac, Kragujevac, Serbia, because of hoarseness and also irritant and non-productive cough, globus pharingeal, throat cleaning and dysphagia. We performed detailed history and physical examination: anamnesis, indirect laryngoscopy with complete otorhinolaryngologic examination and referred patient to foniatric department of Clinic of Otorhinolaryngology, Clinical center Kragujevac, Kragujevac, Serbia to performed rigid endovideostroboscopy. In anamnesis, we found that she has undergone general anesthesia for 8 times, in the early childhood at the age of 3 and 4. The main reason for this invasive method was recurrence of polips in left nasal and maxillar cavities and for last time it was rabdomyosarcoma in epipharyngis, ethmoid cells, left orbit, left nasal and maxillar cavities. Previous clinical, computed tomography and pathohystological examination showed that it was embrional rabdomyosarcoma of botryoid type. Then, radical surgical resection of the tumor was performed, followed by chemotherapy and typically ending with standard course of radiation. Late effects of therapy in our patient were: problems with left eye, bony hypoplasia, orbital and facial asymmetry, direct cardio toxicity and hypertension caused by direct radiation. We must notice that the gonadal development was normal and her behavior was normal following the treatment. Also, she is a good student. It is important because she learns every day and repeats it loudly, so we can conclude that she uses her voice frequently, overuses and misuses.

The patient is directed to allergologist to undergo further analyses. Allergy testing found positive skin prick test to inhalant allergens (pollens of trees, grasses and weeds) and food allergens (banana, nut and peanut). In laryngeal pathology hypersensitive reactions may appear both as etiopathogenetic factors and factors predisponing laryngeal mucosa to effects of the other unfavorable factors

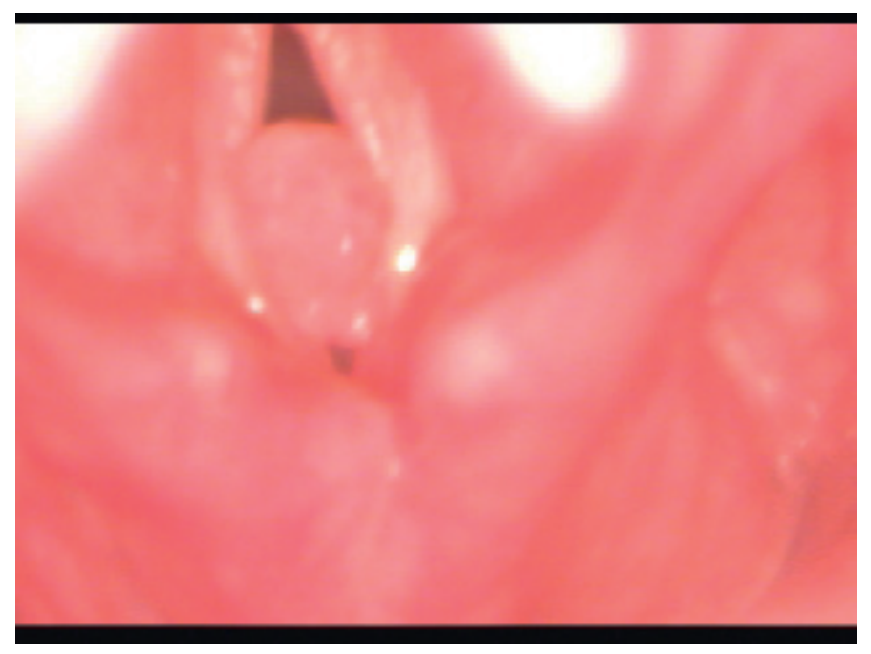

Figure 1. Laryngeal granuloma on the right vocal process area when patient came to examination, caught up from endovideostroboskopy. such as voice overuse and misuse or laryngopharyngeal reflux (6). Throat and nasal bacterial and mycological examinations were negative. In gastroenterological examination the diagnoses of gastroesophageal reflux disease and laryngopharyngeal reflux were made. Our patient uses cardiological and anti-allergic drugs. Indirect laryngoscopy showed hyperemia of laryngeal mucosa, especially in posterior parts, the movement of the both sides of larynx was symmetric. Airway was not compromised. There is the insufficiency of glottis occlusion with noise in speech sound, accompanied by hyperkinesia of the phonation muscles. On the right vocal process area, tumorous lesion was found, which resembles granuloma by its macroscopics appearance. The dimension of the tumorous lesion was about $6 \mathrm{~mm}$ (Figure 1). Rrigid endovideostroboscopy showed asymmetric and irregular vocal folds vibrations and arising of traveling mucous wave.

We indicated microlaryngosurgery with pathohistological verification, but the general condition of our patient was not so good and the surgical treatment was delayed. Clinical treatment was initiated with proton pump inhibitors, inhalation therapy with corticosteroids and speech therapy (one session per week for two months). After the two months, we performed rigid endovideostroboscopy, and we found reduced hyperfunction, tumor lesion was smaller and the mucosal condition was much better. Clinical treatment was based on elimination of all causal and predisposing factors along with use of proton pump inhibitor (control laryngopharyngeal reflux), inhalation therapy with corticosteroids (have good responds in LG) and speech therapy (reduces hyperfunction) and the size oftumor lesion was slightly regressed (Figure 2).

\section{DISCUSSION}

Laryngeal granuloma is a disease whose etiopathogenesis is not well defined (7). Etiopathogenesis of LG is still undetermined and it is attributed to three predisposing

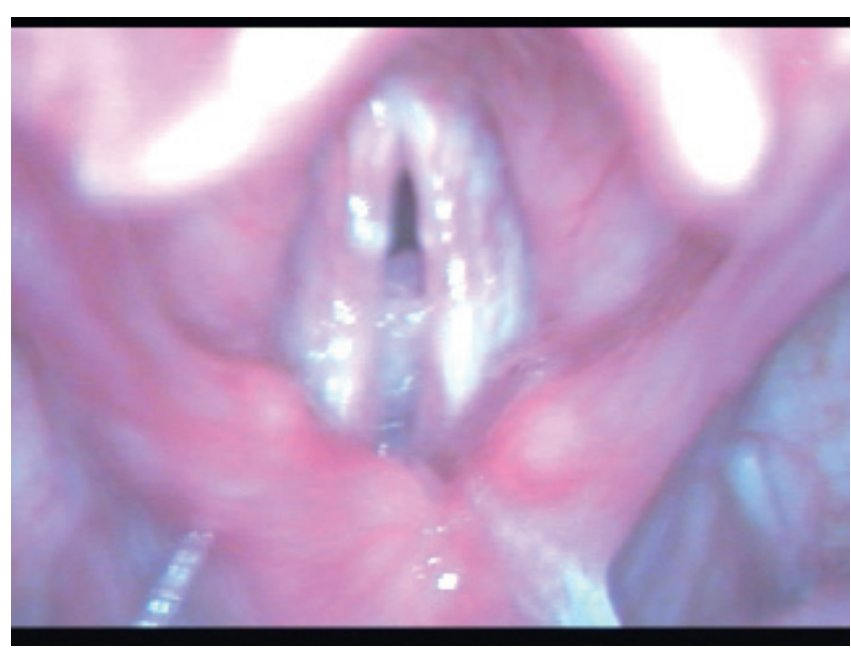

Figure 2. Laryngeal granuloma on the right vocal process area after the treatment, caught up from check up endovideostroboskopy. 
factors: laryngopharyngeal reflux disease, laryngeal intubation and vocal abuse. If none of these causes are found, it is considered idiopathic (8). It is predominant in male subjects, except in cases associated with laryngeal intubation, which has higher incidence in female cases $(7,5)$. Pontes et al. concluded that the higher frequency of intubation-related LG in women is related to lower glottis proportion (9).

As it is known from literature, initially treatment for LG is clinical (10). The surgical treatment is recommended in case of post-intubation related LG. Distribution of remissions after clinical treatment in different etiopathogenesis is: laryngopharyngeal reflux $46.2 \%$, postintubation $44.4 \%$ and vocal abuse $80 \%$ (5). Some authors recommend an observation period of at least six months, but in persistent cases or in differential diagnostic doubts (lupus, sarcoidosis, Wegener's granulomatosis, larynx malignancy...) the surgical treatment with pathohistological verification is necessary, as well as for treating airway insufficiency $(11,12,13,14,15)$. But, do not forget $L G$ is recurrent in about $50 \%$ of cases subjected tosurgical removal. Surgery should be followed by clinical treatment also in the postoperative period to reduce risk of LG recurrence (5).

\section{CONCLUSION}

Laryngeal granuloma affected mainly men, except for cases associated with laryngeal intubation. In our patient etiopathogenic factors were overlapping: laryngopharyngeal reflux, laryngeal intubation and vocal abuse. The clinical treatment in our patient is well responded and general condition is not allow the surgical treatment which was recommended in case of post-intubation related LG. We should keep in mind that postintubation LG might develop after tracheal intubation, so care must be taken to avoid this potential complication.

\section{Conflict of Interest}

There is no financial interest and no other conflict of interest.

\section{REFERENCES}

1. Jackson C. Contact ulcer of the larynx. Ann Otol Rhinol Laryngol 1928;90: 48-52.

2. Wang CP, Ko JY, Wang YH, Hu YL, Hsiao TY: Vocal process granuloma - A result of long-term observation in 53 patients. Oral Oncol.2009;45(9):821-5. http:// www.oraloncology.com/article/S13688375\%2809\%2900026-8/abstract

3. Pickhard A, Reiter R. Benign vocal fold lesions. Laryngorhinootologie. 2013; 92(5):304-12. doi: 10.1055/s0032-1331162. Epub 2013 Jan 24. http://www.ncbi.nlm. nih.gov/pubmed/23348959

4. Hirano S, Kojima H, Tateya I, Ito J. Fiberoptic laryngeal surgery for vocal process granuloma. Ann Otol Rhinol
Laryngol 2002;111(9):789-93. http://www.ncbi.nlm. nih.gov/pubmed/12296332

5. Sataloff RT, Hawkshaw MJ, Gupta R. Laryngopharyngeal reflux and voice disorders: an overview on disease mechanisms, treatments, and research advances. Discov Med. 2010;10(52):213-24. http://www.discoverymedicine. com/Robert-T-Sataloff/2010/09/17/laryngopharyngealreflux-and-voice-disorders-an-overview-on-diseasemechanisms-treatments-and-research-advances/

6. Janosevic Lj, Djukic V, Dotlic J, Stankovic P, Milovanovic A,Janosevic-Dotlic $\mathrm{S}$ et al. Allergic manifestations of the larynx. Acta Clinica 2008;8:105-14.

7. Keiser GJ, Bozentka NE, Gold BD. Laryngeal granuloma: a complication of prolonged endotracheal intubation. Anesth Prog.1991;38(6):232-4. http://europepmc. org/articles/PMC2148694

8. Fink DS, Achkar J, Franco RA, Song PC. Interarytenoid botulinum toxin injection for recalcitrant vocal process granuloma. Laryngoscope.2013;123(12):3084-7. doi: 10.1002/lary.23915.http://onlinelibrary.wiley.com/ wol1/doi/10.1002/lary.23915/full

9. Pontes P, De Biasi N, Kyrillos L, Pontes A. Importance of glottic configuration in the development of posterior laryngeal granuloma. Ann Otol Rhinol Laryngol. 2001;110(8):765-9.

10. Hong-Gang D, He-Juan J, Chun-Quan Z, Guo-Kang F. Surgery and proton pump inhibitors for treatment of vocal process granulomas. Eur Arch Otorhinolaryngol. 2013;270(11):2921-6. doi: 10.1007/s00405-0132527-8.http://link.springer.com/article/10.1007\%2 Fs00405-013-2527-8

11. Karkos PD, George M, Van Der Veen J, Atkinson H, Dwivedi RC, Kim D et al. Vocal process granulomas: a systematic review of treatment. Ann Otol Rhinol Laryngol. 2014;123(5):314-20. doi: 10.1177/0003489414525921. http://www.ncbi.nlm.nih.gov/pubmed/24642585

12. Djukić V, Krejovi-Trivić S, Vukašinović $M$, Trivić $A$, Pavlović B, Milovanović A et al. Laryngeal granulomabenefit in treatment with zinc supplementation? J Med Biochem.2015;34: 228-32. doi: 10.2478/jomb-20140028 http://www.dmbj.org.rs/jmb/pdf/2015-2/10.pdf

13. Nakahira J, Sawai T, Matsunami S, Minami T. Worstcase scenario intubation of laryngeal granuloma: a case report. BMC Research Notes.2014;7:74. doi: 10.1186/1756-0500-7-74 http://bmcresnotes.biomedcentral.com/articles/10.1186/1756-0500-7-74

14. Kumai Y, Yumoto E, Nishimoto K, Minoda R. Retrospective analysis of the clinical course for intubation vs. unspecified laryngeal granulomas. Eur Arch Otorhinolaryngol. 2014;271(5):1129-33. http://link.springer. com/article/10.1007\%2Fs00405-013-2760-1

15. Patel RR, Pickering J, Stemple J, Donohue KD. A case report in changes in phonatory physiology following voice therapy: application of high-speed imaging. J Voice.2012;26(6):734-41. doi: 10.1016/j. jvoice.2012.01.001. http://www.jvoice.org/article/S0892$1997 \% 2812 \% 2900002-1 / p d f$ 